\title{
Metode PERT untuk Efektifitas Waktu pada Sistem Informasi Akuntansi Penjadwalan Penagihan Piutang Berbasis Client Server
}

\author{
Haryo Kusumo ${ }^{1}$, Jarot Dian Susatyono², Sindhu Rakasiwi ${ }^{3}$ \\ ${ }^{1}$ Komputerisasi Akuntansi, Universitas Sains dan Teknologi Komputer \\ ${ }^{2}$ Sistem Komputer, Universitas Sains dan Teknologi Komputer \\ ${ }^{3}$ Manajemen Informatika, Universitas Sains dan Teknologi Komputer \\ haryo@stekom.ac.id, jarot@stekom.ac.id, sindhu@stekom.ac.id
}

\begin{abstract}
$C V$. SHIBA AZAKI is a company engaged in the garment sector, established in 2005. The product marketing area covers areas within the city, outside the city and several areas outside Java. Producing good quality home and baby equipment. In managing a business, there are many problems faced, one of which is billing scheduling. The absence of definite standards in scheduling billing causes delays in the billing process, billing does not match the due date. To overcome this problem, a Scheduling Information System for the location of the billing process was created using the client server-based PERT (Project Evaluation and Review Technique) method. The results of the research are in the form of application products that have been validated and declared to be able to meet the objectives and are expected to help improve the effectiveness of billing location scheduling.
\end{abstract}

Keywords: Scheduling, Billing, Information Systems, PERT Method

\begin{abstract}
Abstrak
CV. SHIBA AZAKI merupakan perusahaan yang bergerak dibidang garmen, berdiri sejak tahun 2005. Area pemasaran produk meliputi daerah dalam kota, luar kota dan beberapa daerah di luar pulau jawa. Memproduksi perlengkapan rumah dan perlengkapan bayi dengan kualitas yang baik. Dalam mengelola suatu usaha banyak masalah yang dihadapi salah satunya yaitu penjadwalan penagihan. Tidak adanya standar yang pasti dalam melakukan penjadwalan penagihan menyebabkan keterlambatan dalam proses penagihan, penagihan tidak sesuai jatuh tempo. Untuk mengatasi masalah tersebut maka dibuat sebuah Sistem Informasi Penjadwalan lokasi proses penagihan dengan metode PERT (Project Evaluation and Review Technique) berbasis client server. Hasil penelitian berupa produk aplikasi yang telah divalidasi serta dinyatakan dapat memenuhi tujuan dan diharapkan dapat membantu meningkatkan efektifitas penjadwalan lokasi penagihan
\end{abstract}

Kata Kunci : Penjadwalan, Penagihan, Sistem Informasi, Metode PERT 


\section{Intoduction}

Perkembangan teknologi informasi saat ini telah berkembang pesat, dimana hampir semua bidang aplikasi bisnis telah memakai dan mengembangkan sistem informasi dengan sedemikian rupa sehingga mampu memajukan dan mengembangkan usaha dengan sangat baik (Fauzia, 2020).

CV. SHIBA AZAKI merupakan perusahaan yang bergerak dibidang garmen, berdiri sejak tahun 2005. CV. SHIBA AZAKI mulai berkembang dari yang hanya memiliki 5 orang karyawan sekarang sudah memiliki 30 orang karyawan. Produk yang dihasilkann oleh CV. SHIBA AZAKI diantaranya sprei, bedcover, bantal tidur, guling dan perlengkapan bayi. Sasaran pemasaran produk yaitu swalayan serta toko meubel. Area pemasaran produk diantaranya di Semarang, Solo, Jogja, Purwokerto, Magelang, Temanggung, Kudus, Pati, Cirebon, Pemalang, Bogor serta beberapa daerah di luar jawa diantaranya Banjarmasin, Pekanbaru, Gorontalo, Makassar, Batam, dan Manado. Dalam satu minggu ada 30 toko yang harus dikunjungi di area jawa, sedangkan untuk area luar pulau jawa jadwal kunjungan dilakukan setiap 2 atau 3 bulan sekali ada 5 sampai 6 toko yang harus dikunjungi. Dalam mengelola suatu usaha, banyak masalah terkait kegiatan operasi yang dihadapi perusahaan, salah satunya adalah scheduling atau penjadwalan (Widiasmara, 2014). Semua perusahaan membutuhkan scheduling yang baik untuk memberikan pelayanan yang baik kepada konsumen. Scheduling dalam perusahaan tidak kalah penting dengan elemen-elemen manajemen operasi yang lain (Susanto, 2013).

Dalam mengelola penjadwalan proses penagihan ke customer $\mathrm{CV}$. SHIBA AZAKI mempunyai kendala. Masalah perusahaan dalam melakukan penjadwalan penagihan ke customer disebabkan oleh budaya perusahaan yang memang kurang konsisten, tidak adanya standar yang pasti mengenai prosedur penjadwalan penagihan yang bisa menjadi patokan sehingga terjadi keterlambatan dalam proses penagihan, dan penagihan yang tidak sesuai jatuh tempo. Penentuan urutan lokasi penagihan juga menjadi salah satu kendala yang dihadapi oleh perusahaan dalam proses penagihan. Dalam melakukan proses penagihan pada tiap toko membutuhkan waktu lama karena jarak antar toko yang relatif jauh dan jam kerja toko yang terbatas. Hal ini membuat beberapa toko menjadi tidak terjangkau untuk dilakukan penagihan. Semua hal tersebut sering mengakibatkan hasil yang kurang efektif serta tidak efisien.

$$
\text { Untuk bisa mengatur dan }
$$
mengorganisasikan setiap informasi tentang penjadwalan penagihan yang ada, tentunya 
diperlukan suatu sistem informasi yang akurat, terpercaya, mudah di akses serta tersusun rapi dan terintegrasi dengan baik (Kusumaratri \& Purwanto, 2020). Perusahaan membutuhkan data waktu, data kegiatan sebagai dasar penjadwalan proses penagihan (Mulyadi, 2014). Untuk melakukan penjadwalan proses penagihan dibutuhkan sistem yang dapat memenuhi nilai perkiraan yang valid, sehingga keluaran yang dihasilkan oleh sebuah sistem dapat digunakan sebagai dasar penjadwalan proses penagihan ke customer (Xiao \& Shao, 2020).

Salah satu alternatif yang dapat diajukan adalah dengan menggunakan Sistem Informasi penjadwalan proses penagihan berbasis client server. Kelebihan dari jaringan client server adalah mengenai akses data yang lebih optimal. Setiap client yang sudah terhubung ke dalam jaringan client server ini sudah pasti akan memperoleh data dan juga informasi yang sama persis dengan apa yang terdapat pada server. Hal ini akan membantu mempermudah proses komunikasi antar client, dan juga tentu saja akan sangat membantu dalam mencegah terjadinya miskomunikasi, baik di dalam jaringan komputer itu sendiri, maupun terjadinya miskomunikasi antar user yang menggunakan jaringan tersebut.
Dalam penelitian ini penulis menerapkan metode PERT yaitu salah satu metode yang bertujuan untuk mengurangi adanya penundaan, maupun gangguan, serta mengkoordinasikan berbagai bagian suatu pekerjaan secara menyeluruh dan mempercepat selesainya proyek (Abdurrasyid et al., 2019). Diharapkan dengan menggunakan sistem ini dapat membantu perusahaan untuk menjadwalkan penagihan secara lebih efektif dan efisien. Sekaligus akan mendisiplinkan pihak perusahaan sebagai pemilik piutang melakukan penagihan secara teratur, terjadwal dan konsisten (Retnosari, 2020).

\section{Materials and Methods}

\subsection{Metode PERT}

PERT atau Project Evaluation and Review Technique adalah sebuah model Management Science untuk perencanaan dan pengendalian sebuah proyek. Teknik PERT (Project Evaluation and Review Technique) adalah salah satu metode yang bertujuan untuk mengurangi adanya penundaan , maupun gangguan pekerjaan, serta mengkoordinasikan berbagai bagian suatu pekerjaan secara menyeluruh dan mempercepat selesainya proyek (Roziya, N. A., Purnamasari, I., \& Wasono, 2018). Teknik ini memungkinkan dihasilkannya suatu pekerjaan yang terkendali dan teratur, karena jadwal dan anggaran dari suatu 
pekerjaan telah ditentukan terlebih dahulu sebelum dilaksanakan. Metode PERT menggunakan pendekatan waktu dengan memberikan tiga angka estimasi waktu untuk setiap kegiatan, yaitu waktu yang paling mungkin (most likely estimate) (m) merupakan estimasi waktu yang sering terjadi dibanding dengan yang lain bila aktivitas dilakukan berulang-ulang dengan kondisi yang hampir sama. Waktu optimistik (optimistic estimate) (a)merupakan estimasi waktu tersingkat untuk menyelesaikan aktivitas bila segala sesuatunya berjalan dengan mulus. Waktu demikian diungguli hanya sekali dalam seratus kali bila aktivitas tersebut dilakukan berulang-ulang dengan kondisi yang hampir sama. Waktu pesimistik (pessimistic estimate) (b) merupakan estimasi waktu yang paling lama untuk menyelesaikan aktivitas, yaitu memiliki kendala dalam aktivitas. Waktu demikian dilampaui hanya sekali dalam seratus kali bila aktivitas dilakukan berulang-ulang dengan kondisi yang hampir sama.

$$
T_{e}=\frac{a+4 m+b}{6},
$$

$T_{e}=$ waktu yang diharapkan

$a=$ waktu optimistik

$m=$ waktu yang paling mungkin

$b=$ waktu pesimistik

waktu yang yang diharapkan dari aktivias penagihan piutang yang didapat dari perhitungan digunakan sebagai durasi waktu setiap aktivitas.

\subsection{Karakteristik PERT}

PERT merupakan suatu metoda analitik yang dirancang untuk membantu dalam penjadwalan dan pengawasan kompleks yang memerlukan kegiatan tertentu yang harus dijalankan dalam urutan tertentu, dan kegiatan-kegiatan itu mungkin tergantung pada kegiatan-kegiatan lain (Turang \& Zaini, 2018). Analisa jaringan kerja (network) ini secara umum sangan membantu dalam:

1) Perencanaan suatu proyek yang kompleks.

2) Scheduling pekerjaan-pekerjaan sedemikian rupa dalam urutan yang praktis dan efisien.

3) Mengadakan pembagian kerja dari tenaga kerja dan dana yang tersedia.

4) Scheduling ulangan untuk mengatasi hambatan-hambatan dan keterlambatan keterlambatan.

5) Menentukan trade-off (kemungkina pertukaran) antara waktu dan biaya

6) Menentukan probabilitas penyelesaian suatu proyek tertentu.

\section{Results and Discussion}

Perancangan sistem bertujuan untuk mengembangkan sistem lama sesuai dengan kebutuhan perusahaan terkait dengan permasalahan yang terjadi pada perusahaan (Karma \& Susanti, 2018). 
Dalam melakukan suatu perancangan sistem baru ada beberapa langkah utama yang dilakukan yaitu menganalisa data dan mengevaluasi penggunaan sistem yang selama ini digunakan perusahaan (Kusumo \& Rakasiwi, 2020), seperti berikut:

\subsection{Flowchart Sistem Lama}

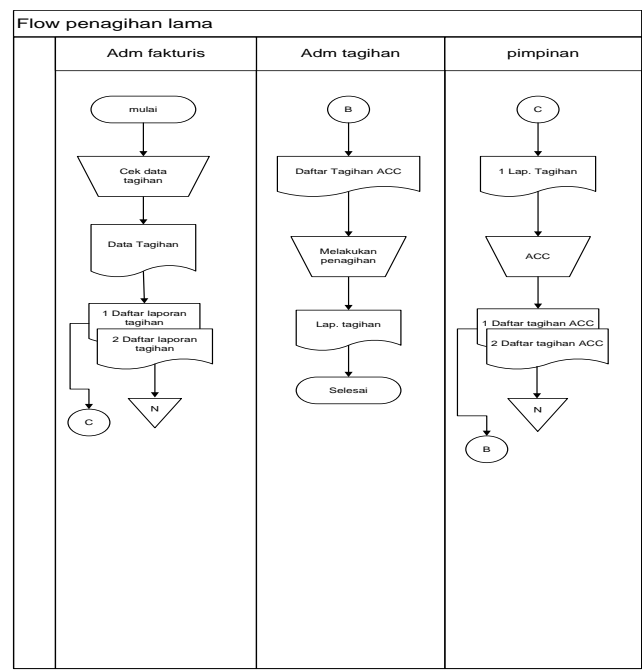

Gambar 1. Flowchart Sistem Lama

Keterangan :

1) Adm Fakturis

Adm Fakturis mengecek data tagihan, kemudian membuat laporan daftar tagihan. Daftar laporan tagihan diserahkan ke pimpinan untuk di ACC.

2) Pimpinan

Pimpinan menerima daftar laporan tagihan dari adm fakturis untuk di ACC. Daftar laporan yagihan yang sudah di ACC diserahkan ke bagian adm tagihan.

3) Adm Tagihan
Adm tagihan menerima daftar laporan tagihan yang sudah di acc oleh pimpinan lalu melakukan proses tagihan. Setelah proses tagihan selesai, adm tagihan memberikan laporan tagihan ke pimpinan.

\subsection{Flowchart Sistem Baru}

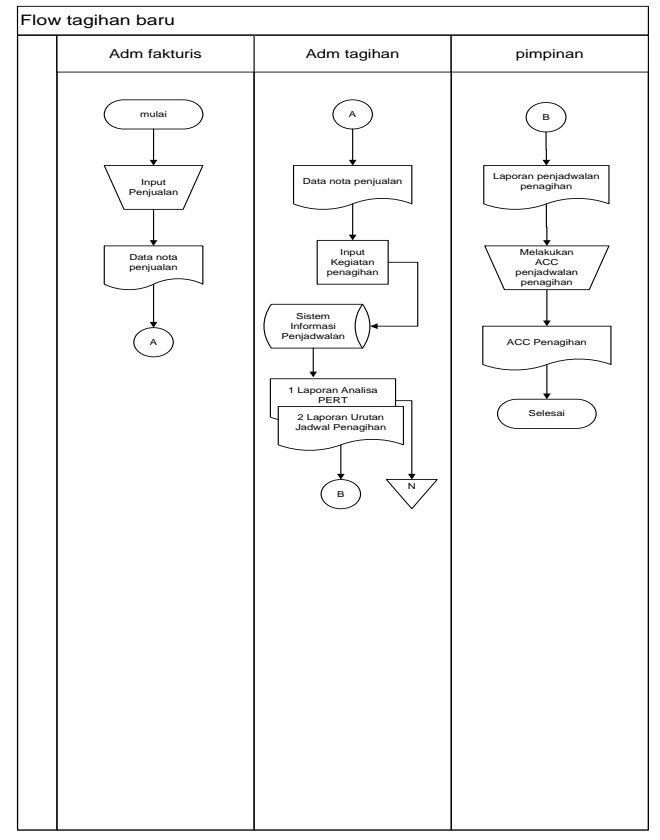

Gambar 2. Flowchart sistem baru

Keterangan :

1) Adm Fakturis

Adm Fakturis menyerahkan nota tagihan ke bagian adm tagihan.

2) Adm Tagihan

Adm tagihan menerima data nota tagihan dari adm fakturis. Kemudian menginput data konsumen dan data tagihan ke database. Setelah itu melakukan penjadwalan penagihan dengan 
menginput kegiatan penagihan.

Cetak hasil penjadwalan penagihan kemudian diserahkan ke pimpinan untuk di ACC.

\section{3) Pimpinan}

Pimpinan menerima laporan penjadwalan penagihan untuk di ACC. Data penjadwalan penagihan yang sudah di ACC diserahkan ke adm tagihan untuk selanjutnya dilakukan proses penagihan ke konsumen.

\subsection{Implementasi Sistem}

Berdasarkan hasil perancangan sistem yang telah dilakukan, maka penerapan Project Evaluation and Review Technique dapat diimplementasikan sebagai berikut :

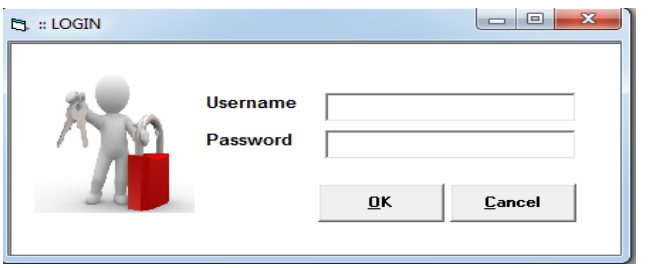

Gambar 3. Form Login

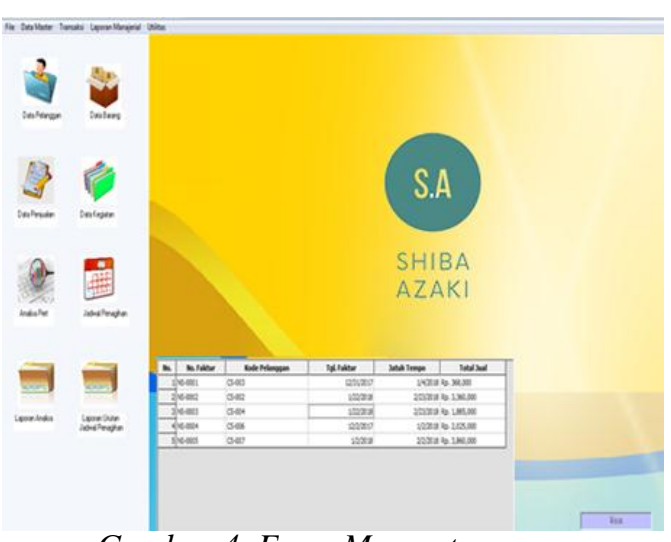

Gambar 4. Form Menu utama

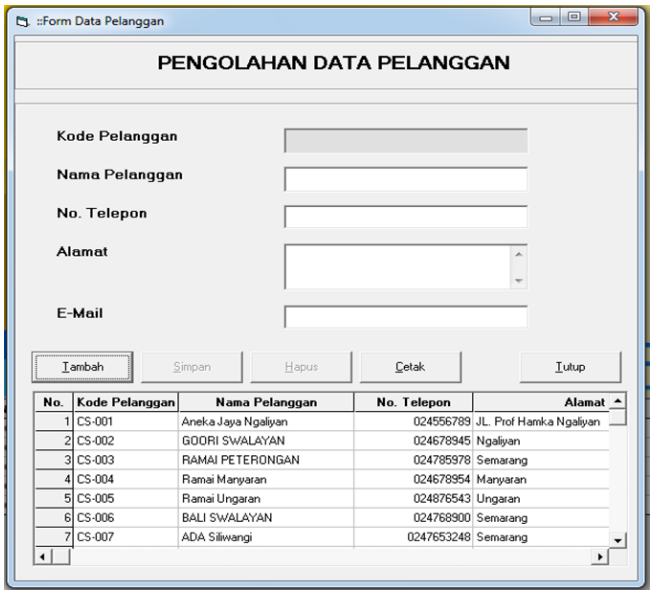

Gambar 5. Form Data Pelanggan

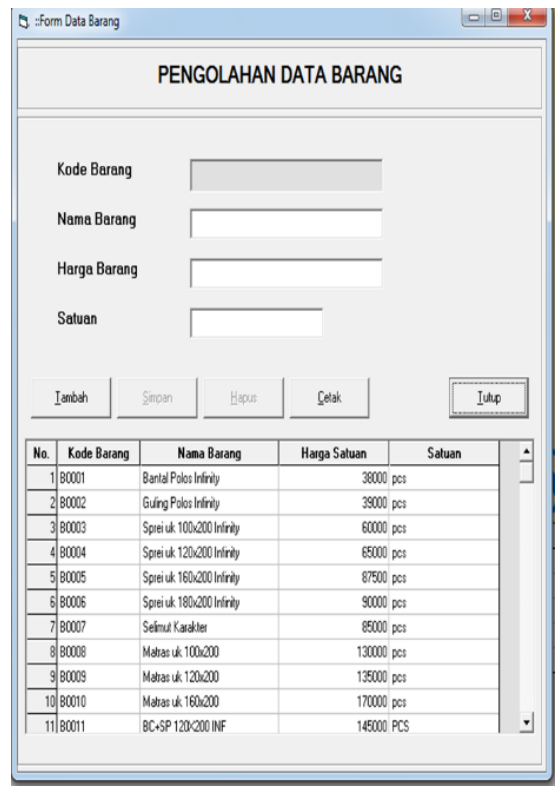

Gambar 6. Form Data Barang

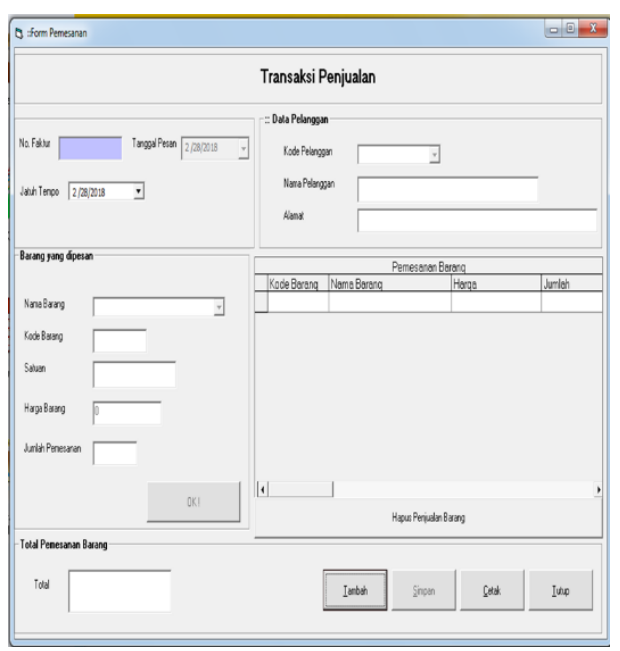

Gambar 7. Form Transaksi Penjualan 


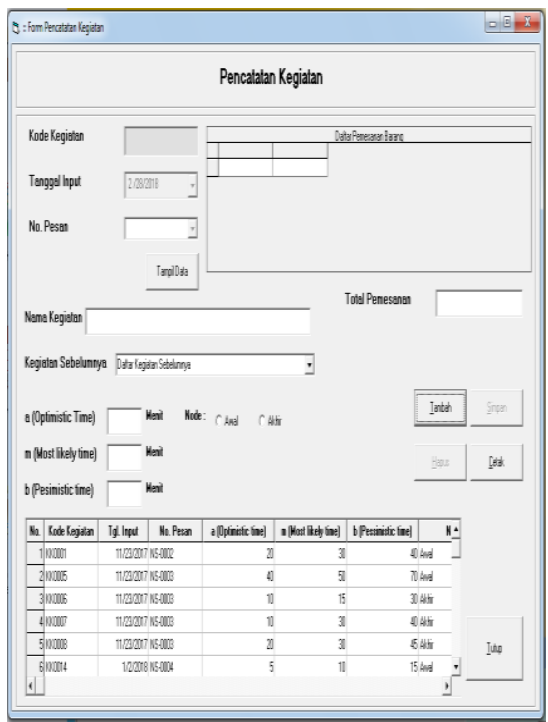

Gambar 8. Form Pencatatan Kegiatan

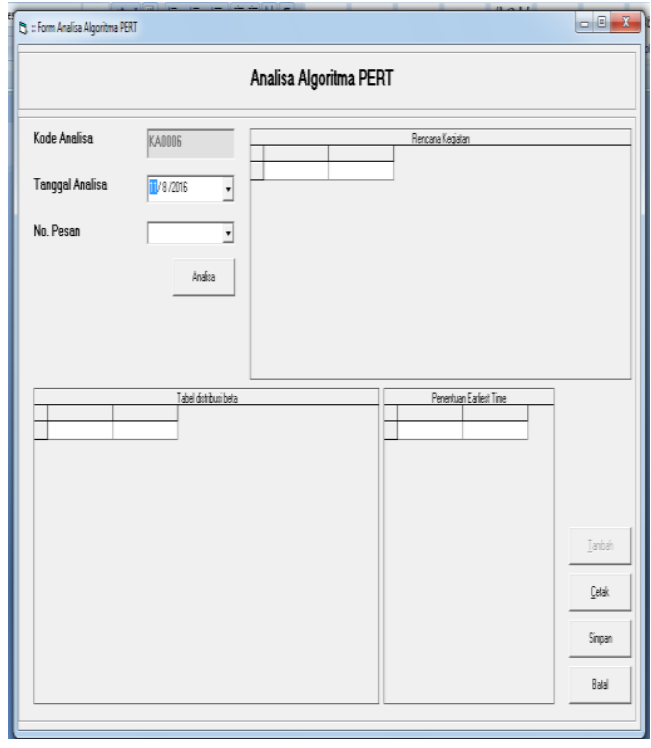

Gambar 9. Form Analisa Algoritma PERT

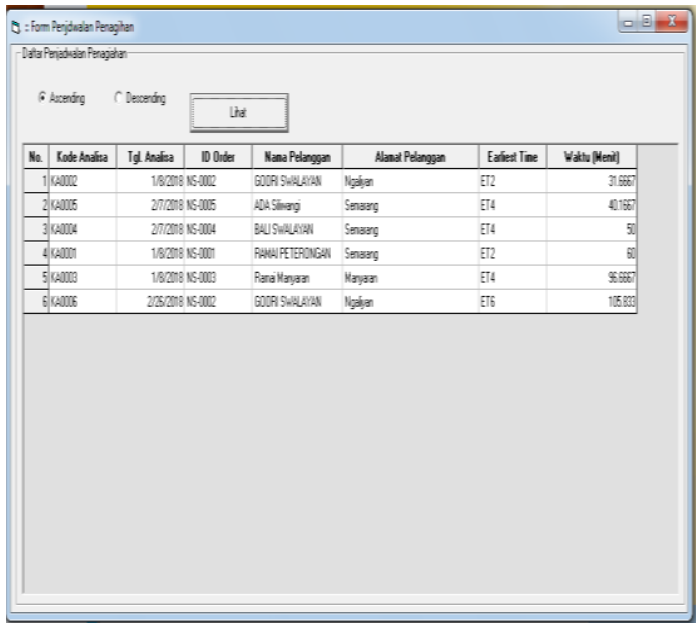

Gambar 10. Form Penjadwalan Penagihan

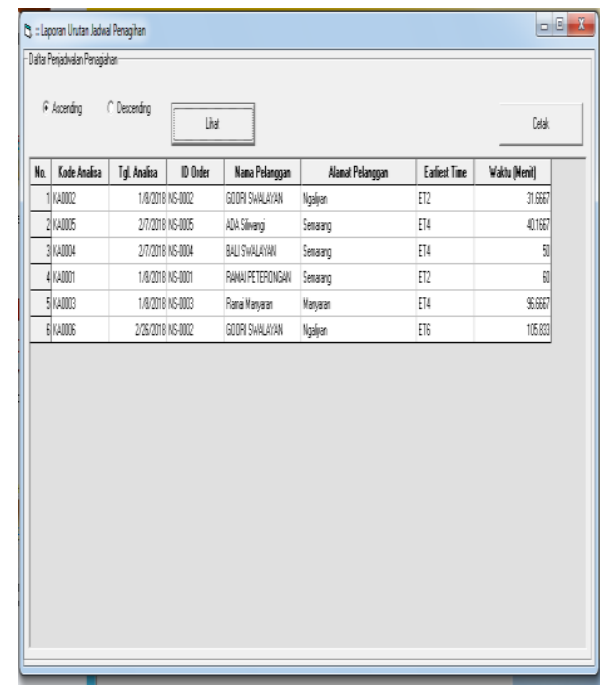

Gambar 11. Tampilan Laporan Urutan Penjadwalan

\subsection{Pengujian Sistem}

Setelah tahap implementsi atau pembuatan sistem selesai, tahap selanjutnya adalah melakukan pengujian sistem. Pengujian sistem adalah proses menilai program, pengujian sistem ini dilakukan dengan cara menghadirkan pakar atau tim ahli yang sudah berpengalaman untuk menilai produk yang dirancang. Subyek pengujian sistem ini terdiri dari ahli pakar sistem, dan user/pengguna. Masing-masing subyek penguji sistem diberi lembar penilaian atau kuisioner penilaian kemudian mereka diminta untuk memberikan penilaian terhadap sistem yang sudah dirancang dengan metode perhitungan sebagai berikut:

$$
\mu=\frac{\sum x}{n}
$$

Keterangan :

$\mu \quad=$ Nilai rata-rata

$\sum x=$ Jumlah total nilai validasi

$\mathrm{n} \quad=$ Jumlah validator 
Table 1. Skala Kriteria Validasi

\begin{tabular}{|c|c|}
\hline Nilai & Kriteria Kevalidan \\
\hline $3,26-4,00$ & Sangat Valid \\
\hline $2,51-3,25$ & Valid \\
\hline $1,76-2,50$ & Kurang Valid ( revisi \\
& Tidak Valid ( revisi \\
& total ) \\
\hline $1,00-1,75$ & \\
\hline
\end{tabular}

\section{Conclusions}

Dengan menggunakan system informasi penjadwalan lokasi penagihan dengan metode PERT (Project Evaluation and Review Tehnique) berbasis client server dapat membantu admin bagian tagihan untuk membuat jadwal penagihan ke konsumen berdasarkan urutan lokasi penagihan sesuai dengan hasil laporan urutan penjadwalan saerta bisa mengontrol tagihan yang sudah jatuh tempo sesuai dengan notifikasi yang muncul ketika program pertama kali di buka. Hasil uji validasi yang dilakukan oleh pakar sistem menunjukan nilai 3,0 berada diantara 2,51 3,25 yakni tergolong dalam kategori Valid. Dan pakar sistem menyimpulkan bahwa sistem berfungsi dengan baik dan membantu meningkatkan efektifitas penjadwalan lokasi penagihan.

\section{References}

Abdurrasyid, A., Luqman, L., Haris, A., \& Indrianto, I. (2019). Implementasi Metode PERT dan CPM pada Sistem Informasi Manajemen Proyek Pembangunan Kapal. Khazanah Informatika: Jurnal Ilmu Komputer Dan Informatika. https://doi.org/10.23917/khif.v5i1.706 6

Fauzia, K. (2020). Perancangan Sistem
Informasi Akuntansi Piutang Usaha Berbasis Web Menggunakan PHP dan MySQL. Jurnal Tekno Kompak. https://doi.org/10.33365/jtk.v14i2.746

Karma, I. G. M., \& Susanti, J. (2018). Development of Account Receivable and Payable System for Travel Bureau Company. Journal of Physics: Conference Series. https://doi.org/10.1088/17426596/953/1/012097

Kusumaratri, R. D., \& Purwanto, P.-. (2020). PERANCANGAN SISTEM INFORMASI AKUNTANSI PIUTANG PADA CV MENANG SENTOSA. SISTEMASI. https://doi.org/10.32520/stmsi.v9i2.71 2

Kusumo, H., \& Rakasiwi, S. (2020). Sistem Pendukung Keputusan Rekrutmen Pada Perusahaan Outsourcing Berbasis Web. Jurnal Ilmiah Ekonomi Dan Bisnis.

Mulyadi. (2014). Sistem Akuntansi Edisi 4. In Salemba Empat.

Retnosari. (2020). Sistem Informasi Pengendalian Piutang Tak Tertagih. JURNAL AKUNTANSI DAN EKONOMI.

Roziya, N. A., Purnamasari, I., \& Wasono, W. (2018). Penjadwalan Proyek Dengan Metode Program Evaluation and Review Technique(PERT). Jurnal Eksponensial,.

Susanto, A. (2013). Sistem Informasi Akuntansi: Struktur Pengendalian Risiko Pengembangan: Edisi Perdana. Lingga Jaya, Bandung.

Turang, D. A. O., \& Zaini. (2018). Perancangan Manajemen Proyek Sistem Informasi Akademik Dengan Critical Path Method Dan Program Evaluation and Review Technique. INTEK: Jurnal Informatika Dan 
Teknologi Informasi.

Widiasmara, A. (2014). Analisis Pengendalian Intern Piutang Usaha Untuk Meminimalkan Piutang Tak Tertagih (Bad Debt) Pada Pt.Wahana Ottomitra Multiartha, Tbk Cabang Madiun. Jurnal Ekonomi MODERNISASI. https://doi.org/10.21067/jem.v10i2.780

Xiao, C., \& Shao, Y. (2020). Information system and corporate income tax enforcement: Evidence from China. Journal of Accounting and Public Policy.

https://doi.org/10.1016/j.jaccpubpol.20 20.106772 